\section{SEROLOGICAL TESTS FOR STAPHYLOCOCCAL INFECTION}

\author{
BY
}

C. H. LACK, M.B., B.S.

Honorary Consultant Pathologist, Reader in Bacteriology. University of London

AND

ADELINE G. TOWERS, M.B., B.S., B.Sc. Lecturer, Department of Pathology

From the Department of Pathology, Institute of Orthopaedics, Royal National Orthopaedic Hospital, Stanmore, Middlesex

The need for a reliable serological test for occult staphylococcal infection has long been evident, especially for the diagnosis of lesions of the spine and hip. Earlier reports on the use of the anti- $\alpha$-haemolysin (Lack and Shelswell, 1955; Lack, 1957), and anti-leucocidin tests (Towers and Gladstone, 1958; Towers, 1961) have placed us in a position to compare the value of these two tests; antibodies to staphylocoagulase and staphylokinase have also been measured in the sera of patients with osteomyelitis, and the antibody response to these four antigens is contrasted.

In the known cases of staphylococcal disease serial determinations were made at regular intervals for at least six months, but only the highest titre of each antibody is included in the Tables.

The majority of the patients whose sera we have tested were in the Royal National Orthopaedic Hospital; the remainder were in other hospitals in Britain. The sera were inactivated at $56^{\circ} \mathrm{C}$. for 30 minutes and stored at $-20^{\circ} \mathrm{C}$. until tested. Bacteriological confirmation of the staphylococcal infection was always sought but not always obtained. Antibody levels which rose after the onset of the disease usually fell as the disease subsided.

The methods used in the four serological tests are described in the Appendix to this paper.

\section{Results}

The anti- $\alpha$-haemolysin titres of 463 patients are set out in Table I. Taking 2 units as the upper limit of normal serum, we find that only $2 \%$ of patients who have no evidence of staphylococcal infection show a titre above this level, whereas $78 \%$ of the proved and $48 \%$ of the presumed show this elevation. However, little attention is paid to an isolated test unless the titre is 8 units or over; a rising titre is regarded as pathognomonic.

Anti-leucocidin titres of 347 patients are set out in Table II. Taking 16 units as the upper limit of normal, we find that $70 \%$ of proved cases have raised titres. On the other hand, $6 \%$ of patients with no evidence of

TABLE I.-Anti-alpha-haemolysin Test, 463 Cases. Highest Recorded Titre Used in Each Case

\begin{tabular}{|c|c|c|c|c|}
\hline & $\underset{\substack{\text { Sero- } \\
\text { positive }}}{>4}$ & $\underset{2-4}{\text { Inter- }}$ & $\begin{array}{c}\text { Sero- } \\
\text { negative } \\
<2\end{array}$ & Total \\
\hline Proved staph. & $62(48 \%)$ & $38(30 \%)$ & $28(22 \%)$ & 128 \\
\hline 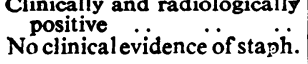 & $\begin{array}{l}24(20 \%) \\
2(1.5 \%)\end{array}$ & $\begin{array}{l}44(28 \%) \\
1(0.5 \%)\end{array}$ & $\begin{array}{r}89(52 \%) \\
175(98 \%)\end{array}$ & $\begin{array}{l}157 \\
178\end{array}$ \\
\hline
\end{tabular}

staphylococcal infection are above this level. Again we stress the importance of a rising titre.

The results of the two tests on the same samples of sera are compared in Table III; in patients with osteomyelitis approximately $16 \%$ show normal levels of both antibodies, and more show a rise in anti-leucocidin than in anti-haemolysin. The two tests used in conjunction may be expected to provide a reliable diagnostic indication in about $80 \%$ of skeletal infection.

Table IV sets out the anti-coagulase titres of 18 patients with proved staphylococcal osteomyelitis whose antibodies to other antigens had been shown to be raised. It indicates that the anti-coagulase titre was raised in only half these patients with respect to the two coagulase antigens available.

Anti-staphylokinase titrations have only recently been introduced ; results on 220 normal sera and sera from 35 patients with osteomyelitis are set out in Table V. If we consider $1 / 20$ to be the highest dilution of normal serum inhibitory to our standard antigen (212 out of 220 normal sera) 9 out of 35 osteomyelitis patients had raised levels. This is a lower percentage than in the group of 7 out of 18 shown in Table IV, but those 18 are comprised within the 35 and were chosen for anticoagulase tests because their other antibodies were raised. When compared with the anti- $\alpha$-haemolysin test the anti-staphylokinase does not show up quite so well ;

\begin{tabular}{|c|c|c|c|c|}
\hline & $\begin{array}{c}\text { Sero- } \\
\text { positive } \\
16 \text { or Over }\end{array}$ & $\begin{array}{l}\text { Inter- } \\
\text { mediato } \\
2-16\end{array}$ & $\begin{array}{c}\text { Sero- } \\
\text { negative } \\
<2\end{array}$ & Total \\
\hline roved staph. & $66(70 \%)$ & $24(25 \%)$ & $5(5 \%)$ & 95 \\
\hline $\begin{array}{l}\text { positive } \\
\text { No clinical evidence of staph. }\end{array}$ & $\begin{array}{c}60(45 \%) \\
7(6 \%)\end{array}$ & $\begin{array}{l}49(37.5 \%) \\
12(10 \%)\end{array}$ & $\begin{array}{c}23(17 \cdot 5 \%) \\
101(84 \%)\end{array}$ & $\begin{array}{l}132 \\
120\end{array}$ \\
\hline
\end{tabular}

TABLE III.-Sera Examined for Diagnosis

\begin{tabular}{|c|c|c|}
\hline All Sera & Antibodies & Osteomyelitis \\
\hline 47 & \multirow{5}{*}{ 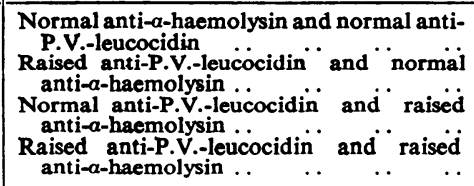 } & \\
\hline 18 & & \\
\hline 5 & & 14 \\
\hline 25 & & 5 \\
\hline & & 24 \\
\hline 95 & Total & 51 \\
\hline
\end{tabular}

TABLE IV.-Anti-coagulase Titrations. Sera from Known Cases of Osteomyelitis Have Boen Examined

\begin{tabular}{c|c|c|c|c}
\hline $\begin{array}{c}\text { Total } \\
\text { No. of } \\
\text { Sera }\end{array}$ & $\begin{array}{c}\text { Raised } \\
\text { Anti- } \\
\text { coagulase }\end{array}$ & $\begin{array}{c}\text { Raised } \\
\text { Anti-a- } \\
\text { haemolysin }\end{array}$ & $\begin{array}{c}\text { Raised } \\
\text { Anti-staphylo- } \\
\text { kinase }\end{array}$ & $\begin{array}{c}\text { Raised Anti-P.V.- } \\
\text { leucocidin }\end{array}$ \\
\hline 18 & $\begin{array}{c}\text { (Raised } \mathbf{M}_{1}, 3 ; \\
\text { raised } \mathbf{D}_{2}, 4 ; \\
\text { both } \mathbf{M}_{1} \text { and } \\
\left.\mathbf{D}_{\mathbf{2}}, 2\right)\end{array}$ & 16 & 7 & 17 \\
\hline
\end{tabular}

TABLE V.-Comparison of Anti- $\alpha$-haemolysin and Antistaphylokinase Levels

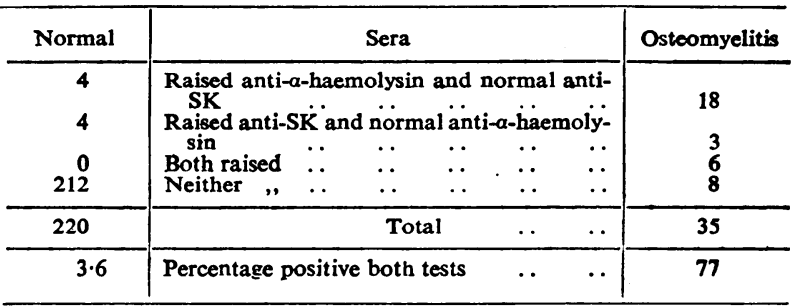


on the other hand, there have been occasions when this antibody had been raised earlier than the others and has provided useful evidence for the diagnosis (see Cases 1,2 , and 3 below).

\section{Case Reports and Antibody Levels}

Case 1.-A man aged 40 came to this country from Ghana with a destructive lesion in $D 10$ and pain in the back for three months. He was being treated as a case of tuberculosis of the spine. Fig. 1 shows his antibody levels after admission. His anti- $\alpha$-haemolysin level remained normal, but both the anti-Panton-Valentine (P.V.) leucocidin and anti-staphylokinase levels were markedly raised; both of the latter levels have fallen slowly to within normal limits as healing proceeded.

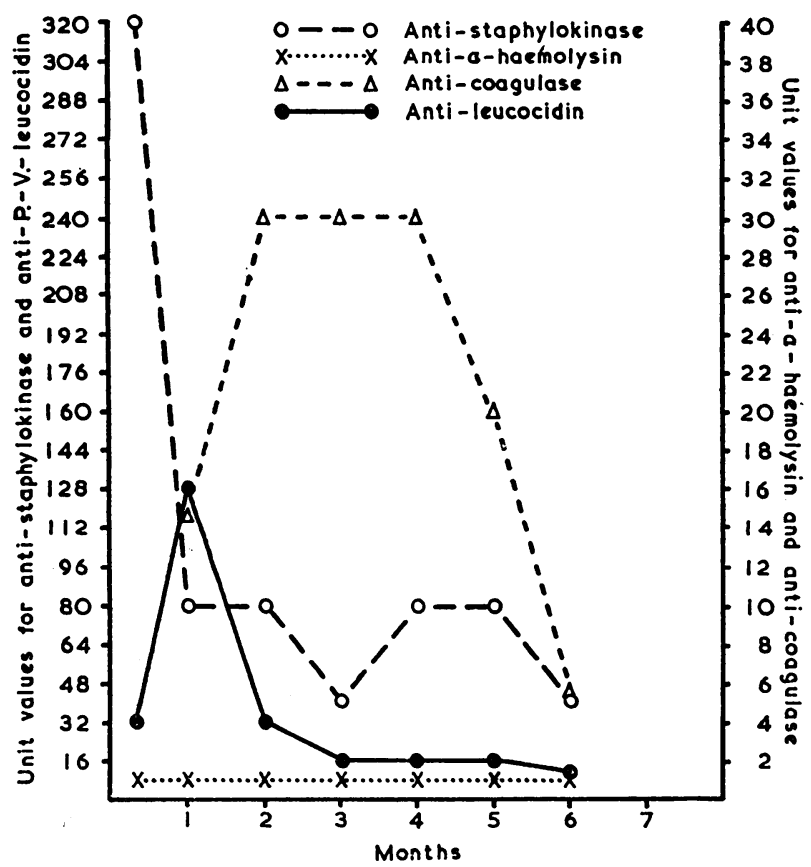

Fig. 1.-Case 1. Antibody levels after admission.

Case 2.-A child of 10 years presented as a case of acute osteomyelitis. Three antibodies were markedly raised, and persisted at high levels, despite continuous and changing antibiotic therapy, until sequestrectomy had been performed (Fig. 2).

Case 3.-A girl aged 6 was admitted to hospital with a history of malaise and pain in the right hip for one week. Her temperature was $103^{\circ} \mathrm{F}$. $\left(39.4^{\circ} \mathrm{C}\right.$.) and no radiological changes could be seen in the affected joint. All four antibodies rose eventually, but the rise in anti-staphylokinase titre and the positive blood culture were the first clues (Fig. 3). This child's leucocyte counts showed a marked leucopenia with a shift to the left during the first month, which may be related to her slow and moderate antileucocidin response.

Case 4.-A boy of 15 fell off a horse and injured his hip. A week later he was admitted to hospital on account of pain and spasm in that joint. The rise of his antibodies is illustrated in Fig. 4. His gamma-globulin and total globulin rose to a level that reversed his $A / G$ ratio (serum total protein $8 \mathrm{~g} . / 100 \mathrm{ml}$. (albumin $2.2 \mathrm{~g}$., globulin $5.8 \mathrm{~g}$.), A/G 0.38). His neutrophil count fell and showed a shift to the left in the Arneth-Cooke count, which subsequently returned to a normal distribution (Fig. 5). His anti-leucocidin did not appear to be protecting his neutrophils completely, which raises the question of whether leucocidin may be produced by ingested staphylococci and be unaffected by antibody in the serum.
The distribution of total leucocyte counts and of neutrophil counts on admission in 13 cases of osteomyelitis is shown in Fig. 6 ; in the majority the proportion of immature neutrophils is increased and the absolute number of mature neutrophils reduced, suggesting that leucocidin has been destroying the circulating neutrophils.

\section{Discussion}

Our experience suggests that at least two serological tests should be used for the diagnosis of cryptic

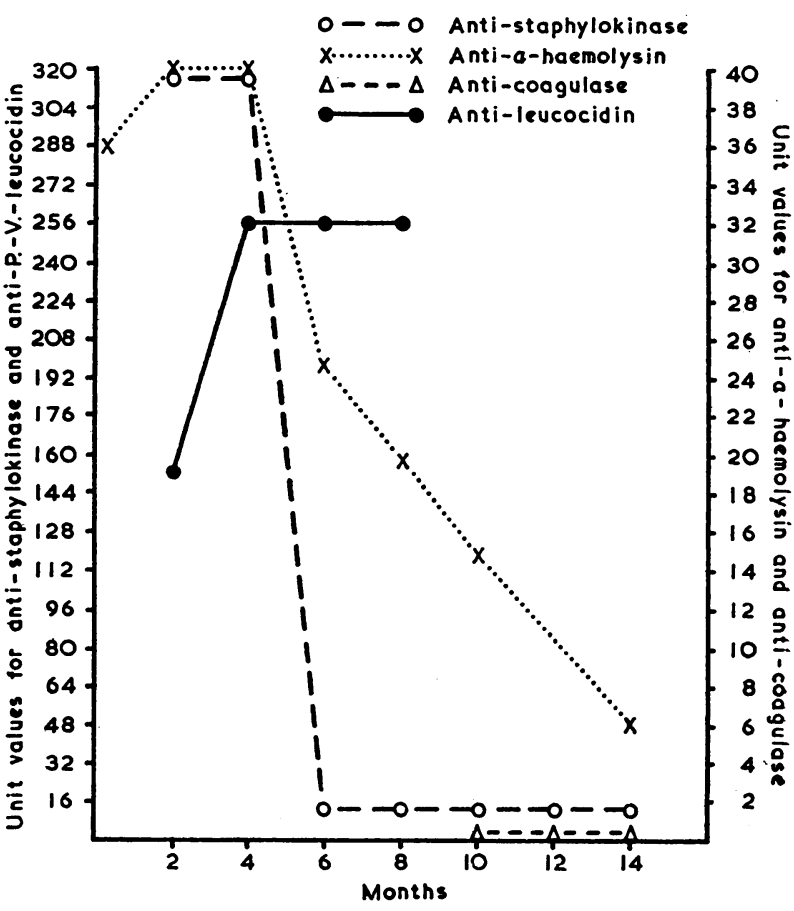

FIG. 2.-Case 2. Showing persistence of antibodies at high levels until sequestrectomy.

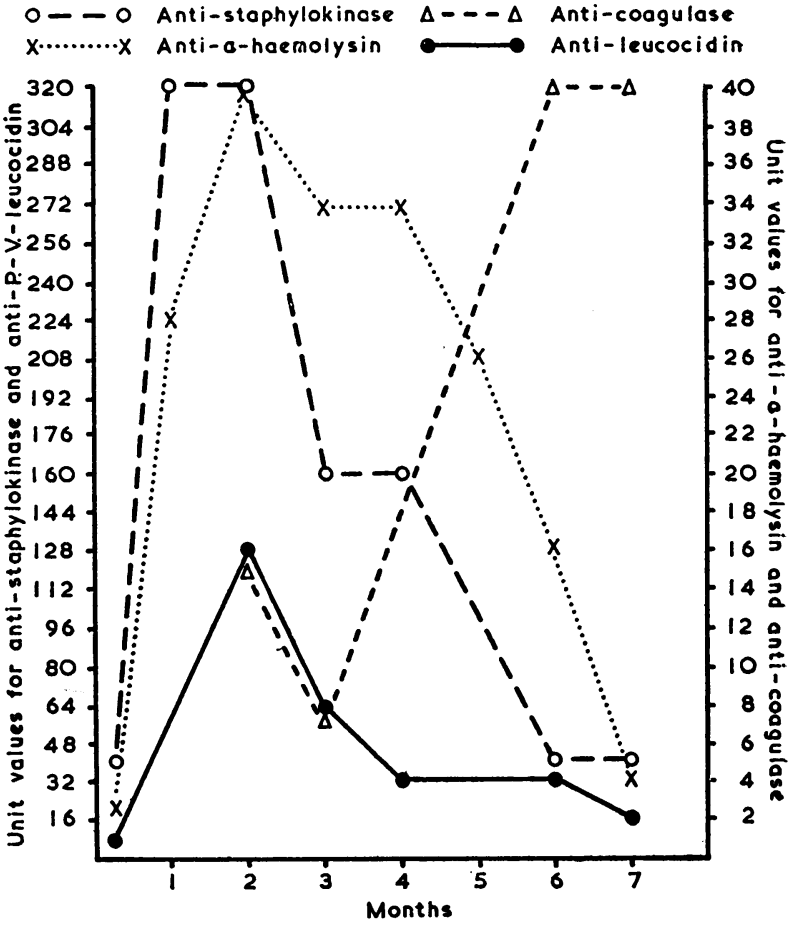

Fig. 3.-Case 3. Showing eventual rise in antibodies. 
staphylococcal infection. Staphylococcal $\alpha$-haemolysin is already available commercially* and it is to be hoped that the same will soon apply to leucocidin.

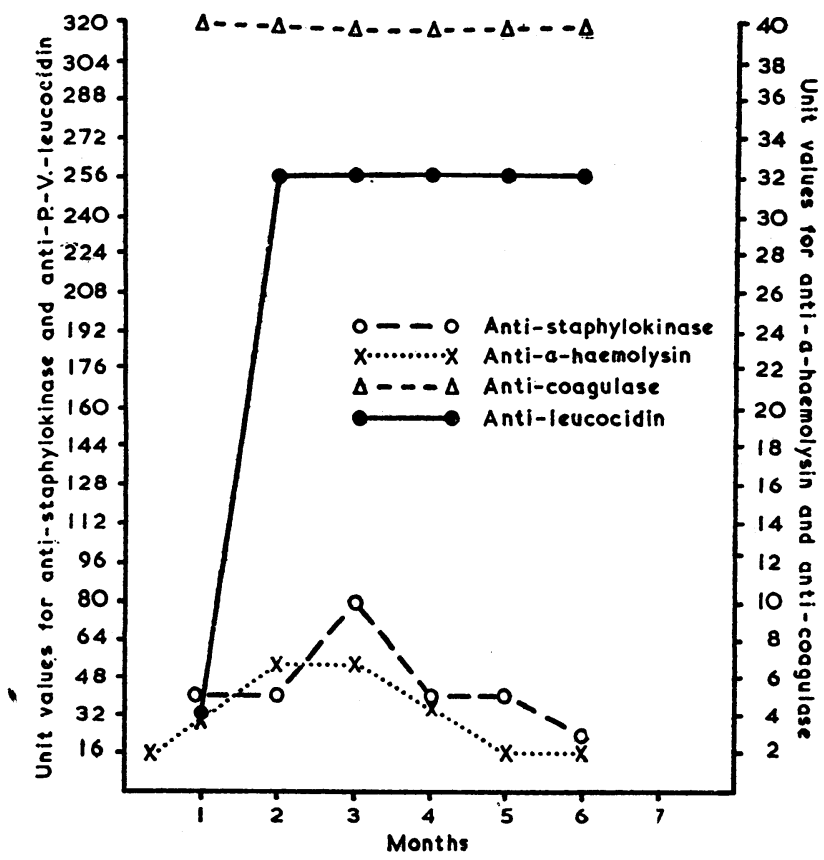

Fig. 4.-Case 4. Showing rise in antibodies.

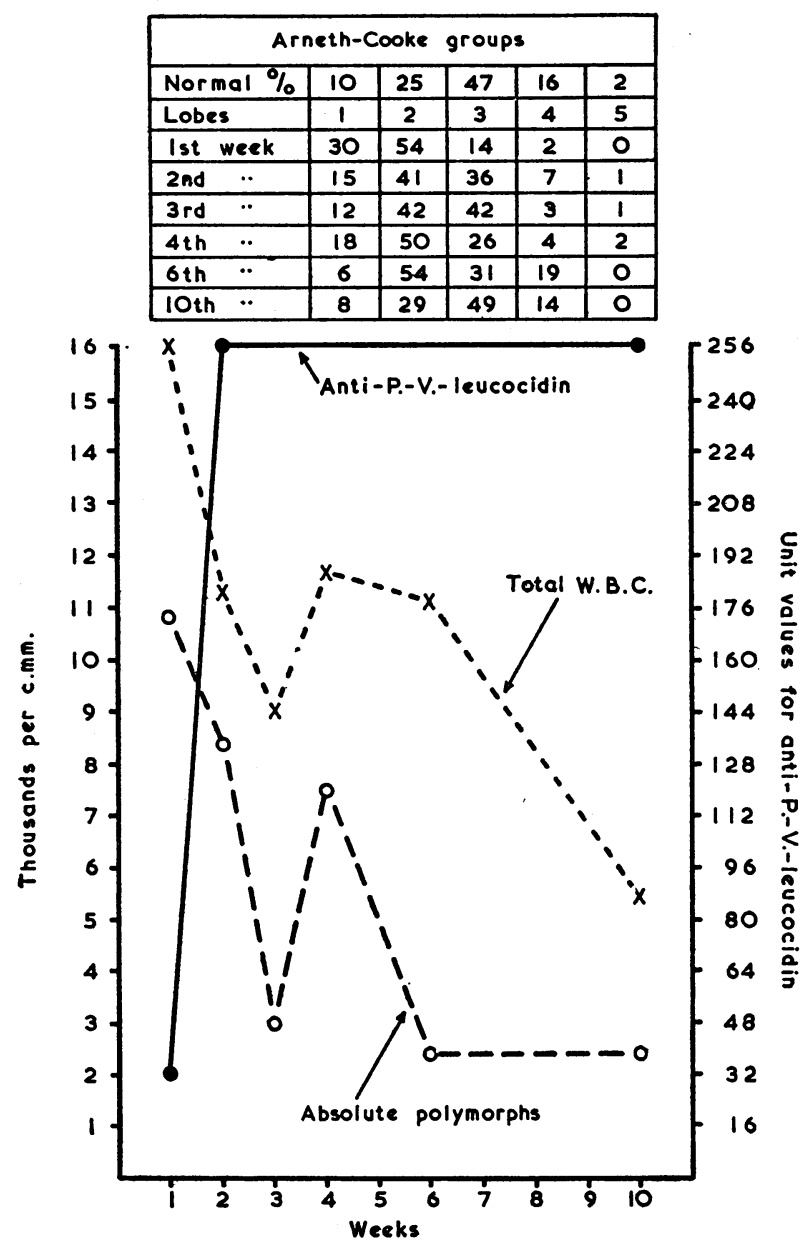

FIG. 5.--Case 4. Changes in neutrophil count in relation to serum anti-leucocidin.
There is evidence which suggests that coagulase and $\alpha$-haemolysin may not be produced by the staphylococcus in the presence of certain tissue components. Rogers (1956) has reported that some macro-anions are able to inhibit the synthesis of extracellular proteins such as $\alpha$-haemolysin, coagulase, and hyaluronidase, and he drew attention to the possible significance of this in a biological setting. Chondroitin sulphate and hyaluronic acid are two acid połysaccharides which are widespread in connective tissue and fall into this category. It is possible that the large amount of hyaluronic acid in the skin is responsible for the inhibition of the antigenic stimulus in infections of this site. There may be little hyaluronic acid in a carbuncle, but such lesions are not usually associated

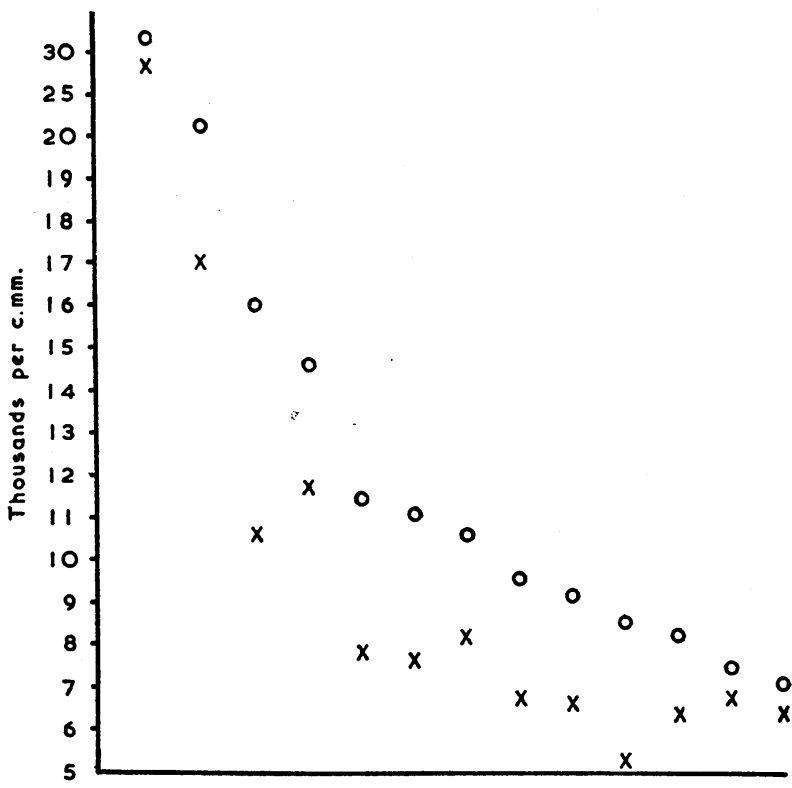

Fig. 6.-Distribution of total leucocyte counts and of neutrophil counts on admission in 13 cases of osteomyelitis. $\mathrm{O}=$ W.B.C. $\times=$ Absolute polymorph count.

with a rise in anti- $\alpha$-haemolysin. Bergman (1957) has reported sodium nucleate, another macro-anion, to be an inhibitor of alpha-toxin production. Staphylococci themselves produce deoxyribonuclease, but possibly their capacity to do so varies as widely between strains as it does with hyaluronidase.

The prevalent idea that staphylococcal infections always evoke a leucocytosis is clearly incorrect; leucopenia and the shift to the left in the Arneth-Cooke count are common and suggest a toxic action on circulating neutrophils. It is hard to say how far this may be prevented by anti-leucocidin in the serum.

\section{Summary}

Four antibodies have been measured during the course of bone and joint infections in a number of patients.

By the methods used, anti-leucocidin levels rose more constantly than anti- $\alpha$-haemolysin ; anti-coagulase levels rose and fell more slowly and were of less help diagnostically. Anti-staphylokinase was often the first to rise but was less constant.

*The Wellcome Research Laboratories, " Diagnostic reagent, staphylococcus $\alpha$-haemolysin (dried)." 
It is suggested that at least two antibodies be measured as a diagnostic aid and that more attention should be paid to rising titres than to single estimation.

We wish to thank our former colleagues, Dr. K. J. Harrison and Dr. F. M. Davidson. for their contributions to these studies, and the American Red Cross for their gift of human fraction III used for the preparation of plasminogen.

\section{APPENDIX \\ Anti- $\alpha$-haemolysin Test Materials}

Wellcome staphylococcal $\alpha$-haemolysin (dried). A stock solution is made from this by diluting with $0.2 \%$ gelatin-saline to a concentration of 20 units $/ \mathrm{ml}$.: $0.1 \mathrm{ml}$. merthiolate is added as a preservative. This is kept in the cold room. Immediately before the test this stock solution is diluted 1/10 with gelatin-saline to give 1 unit of toxin in $0.5 \mathrm{ml}$.

Rabbit red cells.-Freshly drawn thrice-washed rabbit red cells are suspended $10 \% \mathrm{~V} / \mathrm{V}$ in isotonic saline.

\section{MethoD}

The following dilutions of patients' sera are made in gelatinsaline :

$$
\text { Neat } \rightarrow 1 / 2,1 / 4,1 / 8,1 / 16 \text {. }
$$

$1 / 2.5,1 / 5,1 / 10,1 / 20$, in $0.5 \mathrm{ml}$. amounts.

Then $0.5 \mathrm{ml}$. diluted alpha-toxin is added to each tube (1 unit). The dilutions are then as follows:

$$
1 / 2,1 / 4,1 / 8,1 / 16,1 / 32 \text {. }
$$$$
1 / 5,1 / 10,1 / 20,1 / 40 \text {. }
$$

The rack is shaken gently and allowed to stand at room temperature for 30 minutes; $0.1 \mathrm{ml}$. 10\% fresh thrice-washed rabbit cells in saline is added; tubes are gently shaken and placed in $37^{\circ}$ waterbath for one hour.

Controls.-(1) Serum control: $0.5 \mathrm{ml}$. diluted patient's serum (residue of $1 / 16$ dilution); $0.5 \mathrm{ml}$. gelatin-saline; $0.1 \mathrm{ml} .10 \%$ rabbit cells. (2) Saline control: $1 \mathrm{ml}$. gelatin-saline; $0.1 \mathrm{ml}$. $10 \%$ cells. (3) Toxin control: $0.5 \mathrm{ml}$. toxin; $0.5 \mathrm{ml}$. gelatin-saline; $0.1 \mathrm{ml}$. $10 \%$ cells. The controls are put up at the same time as the test and treated in the same way.

\section{Results}

End-point of inhibition of toxin by antitoxin is shown by the tube giving $50 \%$ haemolysis. The titre of the anti- $\alpha$-haemolysin is the denominator of the dilution fractions. Thus if the $1 / 32$ tube shows no haemolysis, and the $1 / 40$ tube shows complete haemolysis, then the titre is given as $32-40$ units $/ \mathrm{ml}$.

Controls.-Haemolysis should be shown only in tube 3 .

\section{Anti-leucocidin Haemagglutination Test Materials}

Standardized Sheep Cells.--Sheep cells in Alsever solution are the most suitable. They are thrice washed in saline and used if there is no trace of haemolysis. $0.5 \mathrm{ml}$. of packed cells is made up to $20 \mathrm{ml}$. in $7.2 \mathrm{pH}$ buffered saline and adjusted so that $1 \mathrm{ml}$. of this suspension plus $9 \mathrm{ml}$. ammoniated water gives a reading of 40 on an EEL colorimeter using filter 625 (green). These standardized cells are ready for tannic-acid treatment and will keep for 24 hours at $4^{\circ} \mathrm{C}$.

Buffered Saline.-Buffered salines at $p \mathrm{H} 6.4$ and 7.2 are made by mixing $100 \mathrm{ml}$. sterile saline with $100 \mathrm{ml}$. of the appropriate $0.15 \mathrm{M}$ phosphate buffers.

N/100 Normal Rabbit Serum (N.R.S.).-1 ml. normal rabbit serum in $100 \mathrm{ml}$. sterile saline.

Tannic acid.-Stock $1 \%$ Merck reagent grade. Store at $4^{\circ} \mathrm{C}$ Dilute $1 / 20,000$ in saline for use.

Preparation of Tanned Cells. $-16 \mathrm{ml}$. standardized sheep cells plus $16 \mathrm{ml}$. 1/20,000 tannic acid are mixed and left at $4^{\circ} \mathrm{C}$. for 30 minutes, then spun gently, washed with $16 \mathrm{ml} . p \mathrm{H} 7.2$ buffered saline, and resuspended in $16 \mathrm{ml}$. saline. It is important to centrifuge gently at all stages in the preparation of the erythrocytes to ensure an even resuspension of sensitized cells.

Panton-Valentine Leucociain Preparation.-The V8 strain Staphy?ococcus aureus is used to produce a culture filtrate slurry rich in leucocidin. Woodin (1959) has published the details of the preparation and fractionation of this slurry. The crude filtrate was obtained from the Microbiological Research Establishment, Porton, Wilts, and the subsequent preparations of fast and slow components of leucocidin were made according to the method given by Woodin (1961). The activity of both fractions was initially checked against neat standard antiserum C.P.P. $76 / 63$ in an ion-agar diffusion plate, precipitation lines becoming visible after 18 hours. The potency of the suspensions kept in saturated ammonium sulphate at $4^{\circ} \mathrm{C}$. has remained unaltered after nine months. Tests have been made using the crude slurry, the fast and slow components mixed in the proportion 10 parts fast to 1 part slow as the sensitizing agent.

Standard Antiserum C.P.P. 76/63.-This has been used throughout the series and was obtained from the Wellcome Research Laboratories, Beckenham, Kent. For use the standard antiserum has been diluted serially $1 / 1,000-1 / 2,560,000$ in N.R.S. All batch fractions of sensitizing agents have been used in concentrations such that the same reproducible overnight pattern of agglutination is obtained with the standard antiserum dilutions.

Sensitization of Tanned Cells. $-\mathrm{pH} 6.4$ buffered saline $64 \mathrm{ml}$ plus antigen (crude slurry, fast, slow, or F+S $0.02-0.06 \mathrm{ml}$. according to batch strength, titrated against standard antiserum) plus $16 \mathrm{ml}$. tanned cells are mixed in that order and left on the bench for 15 minutes. The cells are centrifuged gently, washed once with $32 \mathrm{ml}$. 1/100 normal rabbit serum, and resuspended in $16 \mathrm{ml}$. N.R.S. ready for use.

\section{MethoD}

Tubes of 3 by $\frac{1}{2}$ in. $(7.5$ by $1.3 \mathrm{~cm}$.) are used. Inactivated serum is employed in $0.5-\mathrm{ml}$. quantities serially diluted from $1 / 1,000-1 / 2,560,000$ in N.R.S. Two control tubes using N.R.S. diluent only are set up. Standard antiserum diluted as serum is included with every batch.

Sensitized cells $0.06 \mathrm{ml}$ are added to each of the nine tubes in each test row and to the two control tubes containing $0.5 \mathrm{ml}$. diluent. The rack is well shaken and left on the bench overnight. The tubes are then read over a concave mirror and graded according to the pattern formed by the agglutinated cells. $\mathrm{O}=$ Smooth round button on cells. $+=$ Crenated button or a heavier ring round each ring with a smooth interior. $++=$ Definite agglutination, or with a heavier peripheral ring than + $++t=$ Discrete granular agglutination or a folded edge to the button. The titre is the last tube to show a positive result. "Perspex" racks or flat-bottomed tubes are unsuitable, as no consistent pattern is obtained.

\section{Anti-coagulase Test}

These tests were performed by Dr. K. J. Harrison while she was working in this department; a much larger series are reported in her dissertation for the doctorate of medicine of the University of Bristol (Harrison, 1961).

\section{Materials}

Two coagulases, antigenically distinct and known as $D_{\text {, and }}$ $M_{1}$, were prepared by the method of Duthie and Haughton (1958) and stored in a dried state until required.

Clotting Mixture. -1 in 5 fresh pooled human plasma and $1 / 106 \%$ " filter cel" in $p \mathrm{H} 6.8$ buffer.

Control Serum.-Obtained from a volunteer J.C.F. by withdrawing 1 pint $\left(570 \mathrm{ml}\right.$.) of blood after immunization with $\mathrm{M}_{1}$ and $D_{2}$ coagulase. The serum was divided into small quantities, one of which was thawed when required. The titre of this J.C. F. serum under standard conditions is $M_{1} 1 / 80$ and $D$ $1 / 160$.

\section{MethodS}

$0.2-\mathrm{ml}$. doubling dilutions of patients' and control sera are made in $p \mathrm{H} 6.8$ phosphate buffer. $0.2 \mathrm{ml}$. of dilute assay coagulase in the same buffer is added to each tube and the racks are incubated at $37^{\circ} \mathrm{C}$. for 30 minutes for coupling to occur. The exact dilution for use is found by titration of the minimum clotting dose before each batch of sera was tested. At the end of this time $0.2 \mathrm{ml}$. of the clotting mixture is added to detect the presence of unneutralized coagulase. The tubes are incubated for a further 30 minutes at $37^{\circ} \mathrm{C}$. and read within 10 minutes of removal.

The tubes are recorded as a clot (c), gross floccules $(++)$, or coarse granulation easily visible to the naked eye $(+)$, which is taken as the end-point. If a negative result is followed by a clot in the next dilution, such as may occur at higher titres with doubling dilutions, the end-point is taken as following between two tubes-for example, 1/320 negative; $1 / 640$ clot; titre $1 / 480$. In order that the recorded result should always be comparable, 
final titres are calculated with reference to the J.C.F. control serum. For example. if slight variation in experimental conditions had caused the J.C.F. titre of $D$, to be $1 / 80$ instead of the normal $1 / 160$, the patient's titre is calculated thus:

$$
\frac{\text { J. C. F. titre }}{\text { Patient's titre }} \times 160=\text { corrected titre. }
$$

\section{Anti-staphylokinase Test}

\section{Materials}

(1) Plasminogen, prepared from human fraction III, containing, when activated, $36 \times 10^{-8}$ optical density units per mg. (2) Bovine fibrinogen (Armour) $1 \% \mathrm{~W} / \mathrm{V}$ in $0.85 \% \mathrm{NaCl}$ in distilled water. These two are mixed in the proportion $0.82 \mathrm{ml}$. plasminogen + $9.18 \mathrm{ml}$. bovine fibrinogen solution. (3) Thromhin (Maw) 100 units $/ \mathrm{ml}$. in $50 \%$ glycerol saline. (4) Staphylokinaso-prepared as described by Davidson (1960). (5) Streptokinase ("dornokinase". (6) Serum-serially diluted in saline.

\section{MeThod}

A preliminary staphylokinase assay must be performed to determine the dilution to be used in the antihody titration. Doubling dilutions of staphylokinase in saline in $0.1-\mathrm{ml}$. volumes are made from neat to $1 / 128$ with one control tube containing saline only. $0.1 \mathrm{ml}$. saline, $0.1 \mathrm{ml}$. bovine-fibrinogen-plasminogen solution. and 1 drop thrombin are added to all tuhes, which are well mixed and incubated at $37^{\circ} \mathrm{C}$. for 30 minutes in the waterbath. The end-point is the last tube showing clot lysis. This dilution of staphylokinase is then made up for use in the antistaphylokinase test on patients' serum. A similar assay is made with streptokinase, the end-point being usually of the order of 0.06 Christiansen unit.

Assay of Anti-staphylokinase and Anti-streptokinase.-A 1/10 dilution of patients inactivated serum is made in saline. From this, doubling dilutions are made in saline from $1 / 10$ to $1 / 320$ in $0.1-\mathrm{ml}$. volumes. $0.1 \mathrm{ml}$. of the optimum dilution staphylokinase is added to each tube. A control tube is set up containing saline and staphylokinase only. The tubes are mixed and left to stand at $37^{\circ} \mathrm{C}$. in the waterbath for 30 minutes to allow antigen-antihody combination. $0.1 \mathrm{ml}$. bovine-fibrinogenplasminogen solution is then added to all tubes; the mixture is well shiken. then clotted by adding 1 drop of thrombin to all tubes. The tuhes are incubated at $37^{\circ} \mathrm{C}$. in the waterbath until the control tubes show clor lysis, which should be in 30 minutes, as predeter mined by the preliminary tests without sera. The endpoint of antibody is tuken to be in the last tube showing a solid clot, and has been recorded as this dilution of the patient's serum.

\section{REFERENCES}

Bergman, S. (1957) Acra puth. microbiol scand., 41, 537. Davidson, F. M (1960). Biochem. J. 76, 56 Duthie, E. S., and Haughton. G. (1958). Ibid., 70, 125.

Harrison, $K$, $(|y h|)$. "Coagulase Toxoid in Chronic Furunculosis." M.D thewis. Bristol University.

Lack, C. H. (1457). Pruc. roy. Soc. Med., 50. 625

- and Shelswell. J. H. (1955). J. Bone J1 Surg.. 37B, 135.

Rogers, H. J (1456). Ann. N.Y Acad. Sci, 65, 132

Towers, A. G. (|yh|). J. clin. Path., 14. 161.

Towers, A. G.

Woodin A M. (1959). Biochem. J., 73, 225 .

Woodin A M. (1959). Biochem.

After detailed study of the state of public health in Africa at present W.H.O.'s Regional Committee for Africa has passed a resolution stressing the necessity for closer co-ordination and co-operation between all members in public health and preventive medicine. The same resolution also stressed the urgent need to undertake the training of medical and paramedical personnel in sufficient numbers to fultil the present and future needs of all countries in the Region. In the course of informal discussions on planning for the training of doctors and health workers in Africa the following figures were quoted to show the magnitude of the problem. The Region has an average of one physician per 20,000 inhabitants. Taking as a modest target for the coming 20 years a ratio of one physician per 10.000 inhabitants, Africa would have to be already producing 1.200 medical graduates every year to reach this ngure. The output of existing medical schools is 450 . (W.H.O./39.)

\section{CLINICAL USE OF PEAK FLOW METER}

BY

F. J. FLINT, D.M., M.R.C.P. Consultant Physician, City General Hospital, Sheffield

AND

M. O. KHAN, M.B., B.S.

Formerly Medical Registrar, City General Hospital, Sheffield

The peak flow meter was designed by Wright and McKerrow (1959) as a simple portable instrument for measuring the maximum forced expiratory flow. They found that it could measure obstruction of the airways as efficiently as the more elaborate and bulky machines. Thus the peak flow can be measured as quickly as the blood-pressure.

It is the object of this paper to assess the value of the peak flow meter as an objective clinical test of dyspnoea, and to record the readings obtained from a sample of the healthy population of Sheffield.

\section{Method of Investigation}

The subject was asked to take a really deep breath and then to blow as hard and as fast as possible into the meter through a disposable cardboard mouthpiece. The recorded peak flow rate in each case was the highest of at least three attempts; the test was repeated until it was clear that the maximum had been reached. When it was obvious that co-operation was lacking, as in the case of frail old women or confused patients. the attempt to obtain readings was abandoned. Nearly all the readings were made by the same observer (M. O. K.).

A sample of the healthy adult population was drawn from hospital administrative, clerical. maintenance, nursing, and professional staff, hospital out-patients with no evidence of cardiac or respiratory disense, employees of a large steel works, and ambulant elderly people living in part III hostel accommodation. Thuse with a chronic cough or with known cardiac or respiratory disease were excluded.

The second part of the study concerned the measurement of the peak flow of patients with chronic bronchitis and patients with heart disease. The bronchitic group included hospital patients and persons from the general survey who, on questioning, admitted to a chronic cough during the winter months or throughout the year. The readings obtained from bronchitic subjects were then correlated with the degree of disability. which ranged from dyspnoea on slight effort to frank heart failure: and, within each grade of disability, the bronchitic group was then compared with a group of patients with various forms of heart disease other than cor pulmonale. Before measuring the peak flow, each person was asked the following questions by the same observer: Do you get breathless on walking up hills or stairs? Do you get breathless walking on the flat? Do you get breathless when sitting down or at night ?

The healthy group comprised 622 men and 430 women. The bronchitic group comprised 121 men and the cardiac group 51 men; owing to the relative rarity of chronic bronchitis in women, in the last two groups, only the figures for males are presented. 